\title{
KEYWORD ANALYSIS IN PRESIDENTIAL RHETORIC THROUGHOUT HUNDRED YEARS OF INDEPENDENCE OF ESTONIA, LATVIA AND LITHUANIA: CORPUS LINGUISTIC TOOLS IN CRITICAL DISCOURSE ANALYSIS
}

\author{
LİGA ROMĀNE-KALNIN̦A \\ University of Latvia, Latvia
}

\begin{abstract}
National identity is a complex sense of collectivity that is subjected to the historical, social and geopolitical context of the specific nation that may be addressed and constructed by a person who represents the nation internally and externally. The study illustrates how Critical Discourse Analysis as a relatively new direction of principally qualitative research can use quantitative tools of corpus linguistics for detecting and analysing lexical choice tendencies, the frequency and variation in presidential rhetoric in relation to national identity. The goal of the study was to analyse and compare keyword density in 150 speeches by the presidents of Estonia, Latvia and Lithuania on nationally significant occasions over a century. By combining the Discourse-Historical Approach (henceforth DHA) with keyword analysis and KWIC analysis, the study identifies a common tendency of the presidents of the Baltic States to emphasize their foreign policies and present situation in the countries in terms of independence and national security. It is concluded that the presidents of Estonia give higher prominence to communicating ideas of nationality and statehood while the presidents Latvia and Lithuania emphasise the role of the European Union and NATO in the development of the nations. Notably, historical change seems not to influence the keyword density in the speeches as much as the occasion, political affiliation, gender and nationality of the presidents.
\end{abstract}

Key words: keyword analysis, Critical Discourse Analysis, presidential speeches, national identity, the Baltic States

\section{INTRODUCTION}

National identity and identity discourse have been one of the most widely discussed topics in the past decade. National identity is constructed and represented in the rhetoric of political leaders of countries that both address their 
nations on day-to-day bases and represent the country internationally, thereby potentially influencing the addressees' views. The Baltic States are relatively new countries celebrating their centenary in the year 2018; thus, it is significant to study how the leaders of these countries construct national identities in their public speeches.

The present study uses the DHA, keyword and Key Word in Context (KWIC) analysis to trace the strategies of national identity construction in the speeches of the presidents of the Baltic States. The goal of the research is to analyse and compare keyword density in 150 speeches by the presidents of Estonia, Latvia and Lithuania on nationally significant occasions over a century and identify how keyword analysis can assist CDA in the study of national identity construction. The following research questions have been posed:

1. Which are the most frequently used keywords in the presidential speeches in the Baltic States and how are they used across time and space?

2. What patterns of national identity construction in the speeches do the keywords and their collocates identify?

In order to answer the research questions, a corpus of 150 presidential speeches given by 18 presidents of Estonia (1991-2018), Latvia (1918-2018) and Lithuania (1991-2018) on nationally significant occasions such as the Independence Day and the Restoration of Independence, New Year and song festivals has been compiled (received from the office of the presidents of Estonia and Lithuania and collected from archives in Latvia) and analysed using the third-generation corpus programme AntConc for keyword density analysis and distribution and the forth-generation web programme Sketch Engine (Tomas, $2017)$ to create the corpus online and extract the keywords and collocations. The corpus size is 176980 words (78004 - Estonia (40 speeches), 50538 - Latvia (60 speeches), 48438 - Lithuania (50 speeches)).

The author of the study follows the five most frequently found national identity construction strategies, namely, 1 . The linguistic construction of the 'homo nationalis', 2. The narration and confabulation of a common political past, 3. The linguistic construction of a common culture, 4. The linguistic construction of a common political present and future, 5. The linguistic construction of a 'national body' as described by Wodak, De Cillia, Reisigl and Liebhart (2009: 30) and uses a combination of steps in the DHA and Corpus Linguistic (CL) tools proposed by Baker (2012):

1. Formulation of the topic and the research questions;

2. Background research - context, history, theories;

3. Corpus collection - selection and classification of texts;

4. Corpus-driven analysis - keyword extraction (lemma, at least 50 occurrences);

5. Qualitative/critical analysis of keyword use based on context - forming generalisations and interpretations of how and why the keywords are used; 
6. Corpus-based analysis - critical discourse analysis of co-text or collocation context of the keywords - seeking evidence for the generalisations and interpretations;

7. Drawing conclusions.

The speeches analysed are in Latvian and English; therefore, two available reference corpora have been used for the keyword frequency analysis by the Sketch Engine programme, namely, Latvian Web 2014 and English Web 2014. The example sentences and keywords in Latvian are translated into English accordingly.

\section{CRITICAL DISCOURSE ANALYSIS AND CORPUS LINGUISTICS}

CDA and its methods have become one of the prominent research directions in language research (Flowerdew and Richardson, 2017). Nevertheless, the objectives of CDA and especially the Discourse-Historical Approach (DHA) have been much criticised in terms of their subjectivity and researcher bias, their overall focus on political ideologies (e.g. Joseph, 2006: 130) and lack of in-depth analysis (e.g. Žagar, 2011). Thus, given at times earned and sometimes overexaggerated criticism, methods of CDA have been recently combined with those used in such developing subdisciplines of linguistics as Corpus Linguistics and more specifically statistical analysis of keywords and their collocations.

CL studies large bodies of authentic language samples characterised by 'machine readability, authenticity, representativeness', and allows CDA to analyse how a specific subject is talked about, study the idiolects of specific politicians, make 'corpus comparisons and identify sets of linguistic features' including keywords and their collocations in context (O'Keeffe and McCarthy, 2014: 595). The combination of CDA and CL can be successful, however, by applying two approaches to the analysis of discourse, namely, a corpus-based CDA that 'focuses on a pre-determined hypothesis and seeks linguistic proof for it' and a corpus-driven approach 'is a more inductive type of research that uses corpus data to form hypotheses' rather than test them (Baker, 2012: 15). Corpus-based CDA can thus be used for a detailed analysis of the collocational environment of keywords, the extraction of keywords and most frequently occurring lexical items being a corpus-driven CDA. The combination of these approaches with the DHA can reduce the potential researcher bias and subjectivity but also provide additional material for more detailed qualitative and quantitative critical analysis of national identity discourse. The contributions of Baker (2006 and 2012), O'Keeffe (2006), McEnery and Hardie (2012), Haider (2017), Wodak and Meyer (2016) and Allan (2018) to incorporating corpus tools in the analysis of discourse are used as theoretical and methodological grounds for the research.

\section{NATIONAL IDENTITIES IN THE BALTICS}

National identity is defined as 'a collective sentiment' based upon the belief of belonging to a group sharing social, historical, geographical and linguistic traits, 
a belief in a 'system of cultural representations and imaginary community that is constructed and conveyed in discourse' (Wodak et al., 2009: 11). National identity can be represented in speeches by drawing on 'a range of shared space, [...] shared knowledge and a sense of common identity' which are typically marked through specific language use (O'Keeffe, 2006: 130).

The elements of national identity in the countries under consideration can be best reviewed by looking at the preambles of their constitutions (see Appendix 1). Thus, the elements of national identity such as language, culture, Christian values and freedom are common to the three states. Although it is a responsibility of national governments to sustain the country values, it is widely considered that the responsibility and function of the president (apart from the legislative, judicial and executive functions) of the state are to construct and represent the nation and its identity.

Other elements of national identities of the Baltic States are their cultural celebrations and values such as song festivals, Singing Revolution (at the time of national awakening and restoration of independence of the states in the 1990s), state decorations, the coat of arms and the flag. Likewise, the common political past in the Soviet Union as well as the mass immigration from other countries during the Soviet times that left only around 61 per cent of native Estonians, 52 per cent of native Latvians, and 80 per cent of Lithuanians in the countries at that time has shaped the discourse of inclusion and exclusion (we and the other) in these countries (Lane, 2008; Taagepera, 2018).

\section{KEYWORDS AND CONTEXT IN PRESIDENTIAL SPEECHES}

The first results of keyword analysis (see Appendix 3) show a similar tendency of the presidents of Lithuania and Estonia to emphasize the state name (Estonia ( $n$ / ns), Lithuania(n), keywords are marked in italics for emphasis in all the quotations below), which can be interpreted as construction of the national body and 'homo nationalis', e.g.

- Herewith I would like to underline the key issue: in 1920s for the first time in the history the Estonians became masters not only of their state but also of their land. (Ruutel, 2003)

- They are the reminders of the glorious past of Lithuania not only for us and our youth, but also for the whole of the world. (Brazauskas, 1998)

The most frequently applied keyword in comparison with the reference corpus in the speeches of the presidents of Latvia is lemma 'honour' including the words honourable, honoured, honour, e.g.

- Visi dziḷi izjūt, ka tā diena, kad latviešu apdzīvoto zemi izsludināja par brīvu, neatkarīgu Latvijas valsti, ir turama visaugstākā cieņā, godā, pateicībā un neizdzēšamā piemiñā. (Kviesis, 1934) - Everyone feels it deep in their heart that the day when the Latvian land was declared 
free is to be held in the highest respect, honour, gratitude and indelible commemoration.

Two keywords that are commonly used in the speeches of the presidents of all the three states are independence and freedom (see the list of most frequently occurring keywords in Appendix 3). The use of these values is aimed at the construction of national spirit, common political past, present and future and directed at the feelings of patriotism of the people, e.g.

- At this point, I would like to emphasize once more that it was our people who restored the Estonian independence. (Ruutel, 2003)

- And more important than money is the sense of freedom and security that we are still capable of recognizing. (Ilves, 2012)

- On January 13, 1991, the people of Lithuania defended the independence. (Brazauskas, 1997)

- We will protect Lithuania, its independence, the rights and freedoms of our people. (Grybauskaite, 2018)

- Mēs kopā pirms 20 gadiem atguvām un dziesmotajā revolūcijā nosargājām Latvijas valsts neatkaribu un brivibu. (Zatlers, 2010) - In the singing revolution 20 years ago, we regained and restored the independence and freedom of Latvia.

Further on, the presidents of Estonia seem to be emphasizing democracy of their state and values in relation to the past and countries such as Russia (one of the most frequent and closest by range) collocations found with the keyword democracy/democratic, while the presidents of Latvia and Lithuania emphasize the importance of international cooperation and membership in the $E U$ and NATO in relation to freedom and security pointing both to the common political past in the Soviet Union and future in organisations such UN, e.g.

- The restoration of Estonia's independence was closely connected to the restoration of democracy in Russia. (Ruutel, 2002)

- Svarīgi ir tas, ka ES un NATO radušas pārliecinošas atbildes uz mūsdienu izaicinājumiem un noteikti reagéja uz komunistu reakciju Krievijā. (Ulmanis, G., 1996) - It is important that EU and NATO have found solutions to the current problems in the world and distinctively reacted to the communist behaviour in Russia.

- The road to the European Union will change Lithuania and its people. (Brazauskas, 1994)

- After World War II, Lithuanian partisans testified through their tragic fate that the Stalinist Soviet Union did not destroy the dignity and idealism of Lithuania. (Adamkus, 2013)

As indicated in the examples above, the presidents of all three states mention the Soviet Union or Russia relatively often when referring to security, freedom, 
democracy, independence and international cooperation (see collocations in Appendix 3); however, when having a closer look at the integration of the words into their co-textual environment, it may be concluded that these lexical choices are not only intentional reminders of the unpleasant political past, but also encouragements for future political cooperation and international relations with the former Soviet countries.

Finally, there is a notable difference in the keyword results in the speeches by the presidents of Latvia (see Appendix 3 for the list of most frequently occurring keywords in the speeches), as they emphasize the words Latgale (one of the regions of Latvia that has been most alienated from the other parts of Latvia), people/folk and future in relation to the unity of the Latvian nation, belief in freedom, control over their land and strength of their values, e.g.

- Šeit, Latgalē, ticības spēku mēs varam izjust it īpaši. - We can feel the power of belief more than ever here in Latgale. Sanāksim atkal kopā Latgales sirdī pēc nepilna pusotra mēneša, lai sañemtu svētību mūsu zemei, müsu tautai un müsu Latvijai! - Let us come together in approximately one and a half month in the heart of Latgale to receive a blessing for our land, our people and our Latvia. (Vējonis, 2018)

- Tādēḷ šajā svētku dienā gribu mums novēlēt atgūt kaut daḷu tā spēka un ticības, kas Latvijas tautai piemita 1918. gadā un Atmodas laikā. (Bērziņšs, 2012) - Therefore, on this celebration day I would like to wish you to restore at least a part of the strength and belief that had characterised the Latvian people in 1918 and during the Latvian National Awakening.

- Mēs atkal esam vienoti - vienas zemes dēli un meitas. 15. maijs liek pamatu jaunai nākotnei, par kuras iespējamību daudzi šaubijās, bet kuras nepieciešamību visi atzina. (Ulmanis, K., 1934) - We are unified sons and daughters of one land. May 15 has put grounds or new future, doubted by many, but anticipated by everyone.

It seems that the keywords Latgale and people are most often applied together also with Latvia values such as strength and belief and most frequently in the speeches held on Catholic celebrations and song festivals that can be seen as a strategy of the representation of national spirit and common culture, while the reference to the common political future is most often seen in relation to the past, unity of the people and love for their land as well as international cooperation.

Consequently, as can be observed in the keyword collocation list (Appendix 3) and in the example sentences above, there are several similar tendencies of lexical choices in the speeches of the presidents of the Baltic States that relate to the common political past and national values of the countries that are also emphasized in the preambles of their constitutions. The differences are in the emphasis on national unity versus international cooperation, mention of proper names of the states and their regions as well as mention of cultural values. 
Furthermore, when looking at the historical changes of the specific keyword density, it seems that in the case of the presidents of Estonia there is a slight increase of keyword use during the first fifteen years of the $21^{\text {st }}$ century and a slight decrease since then.

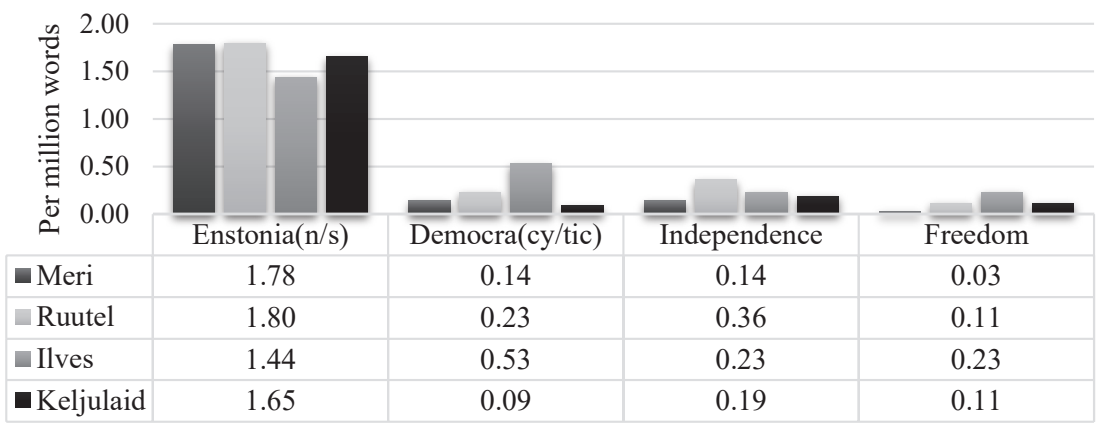

Figure 1 Keyword density in the speeches of the presidents of Estonia

In the case of the presidents of Latvia, the highest keyword density is observed in the period from 1991 to 2015, which can be explained by the political situation in the country (restoration of independence and nationhood) and joining political organisations (UN, NATO, EU).

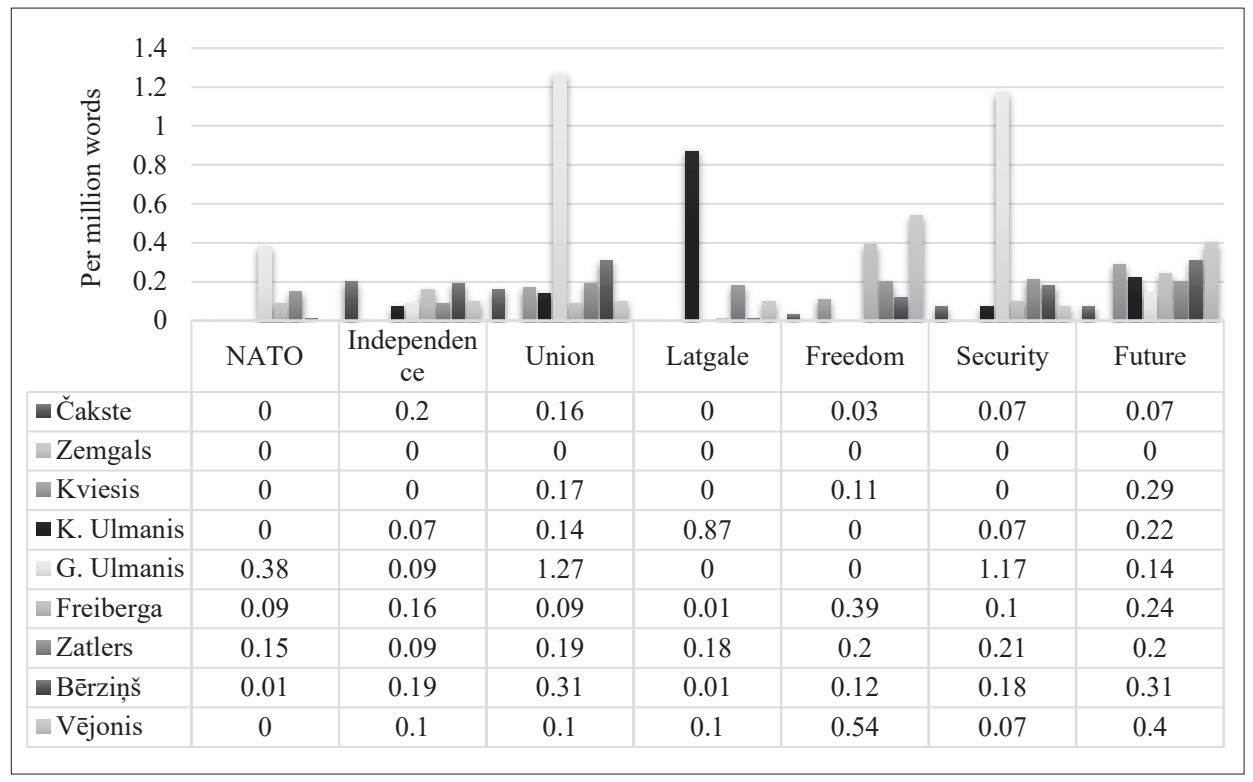

Figure 2 Keyword density in the speeches of the presidents of Latvia 
As with Lithuania, keyword density of the words Lithuania, independence, and freedom seem to be most frequent during the 1990s and during the second decade of the $21^{\text {st }}$ century (a slight increase over time), while the words referring to international cooperation (European, nations, union) are more frequent at the end of the $20^{\text {th }}$ century and during the first years of the $21^{\text {st }}$ century, which marks the time of Lithuania joining international organisations.

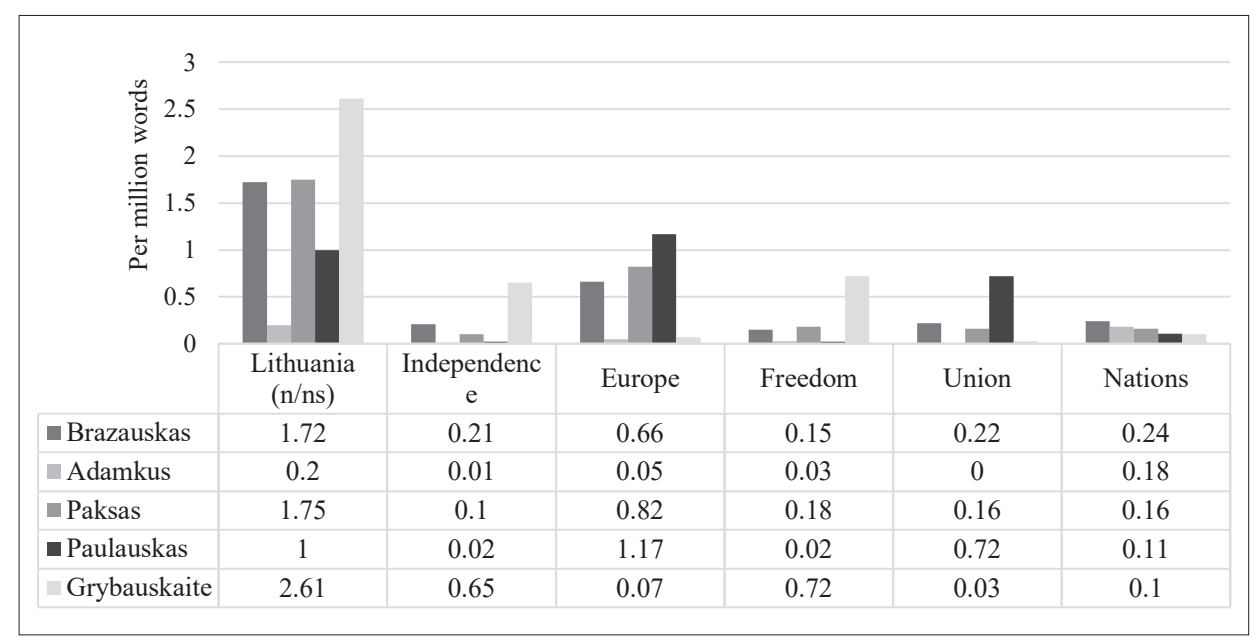

Figure 3 Keyword density in the speeches of the presidents of Lithuania

The figures above display keyword tendencies in relation to their use in the speeches of specific presidents and thus diachronic change, as all the presidents are listed in historical order.

Furthermore, keyword use varies slightly not only when looking at the diachronic and synchronic (across countries) change, but also when choosing such criteria as occasion of the speech, political affiliation of the president and gender of the president for a more detailed analysis. The speeches given at national celebrations such as Independence Day and Restoration of Independence Day emphasize the state name or self-reference as markers of self-definition (Estonia, Latvia, Lithuania), deictic mapping via personal pronouns denoting centring of the speaker and inclusion of the listeners (our - Latvia), national government (Riigikogu-Estonia), and the capital of the state (Vilnius). Likewise, New Year and Christmas speeches emphasize the state name in the speeches of the presidents of all three states, with a slight divergence in keywords that characterise the speech occasion (new year, millennium, happy) in the case of Estonia and Lithuania and inclusive pronoun (our) reference to the state as national body and people as its children in the case of Latvia. The keywords in the international speeches mainly show the tendency of the presidents to emphasize their state and its relations to organisations such as the EU and NATO. Additionally, lexical tendencies in other speeches on such occasions such as song festivals or Catholic celebrations 
in Aglona by the presidents of Latvia seem to be focusing on national values such as love, belief, heart, song and celebrations as well as Latgale.

When looking at the keyword distribution according to the political affiliation or ideology of the president, notable difference is observable in the speeches given by presidents belonging to nationalist parties (L. Meri - Estonia and R. Paksas), who mainly emphasize statehood, independence, government, defence, security, democracy and constitution, while liberal and socialist party representatives (A. Ruutel, T. Ilves, J. Čakste, G. Zemgals, A. Kviesis, G. Ulmanis, A. Bērziņš, R. Vējonis, and A. Brazauskas, A. Paulauskas) emphasize international cooperation, integration, union, stability and also democracy and independence. Presidents having no political affiliation or party independent presidents (K. Keljulaid, K. Ulmanis, V. Vỉke-Freiberga, V. Zatlers, and D. Grybauskaite) emphasize national values such as freedom, security, nation, independence, freedom monument (Latvia), people, political present and future of the states.

Likewise, there is quite notable variation of keyword choice when looking at the male versus female president speeches. Female presidents choose to emphasize national values (freedom, independence, proudness, readiness to work, destiny, care, love and care) as well as centring (inclusive - we, our, us) and othering (exclusive - those) pronouns, while male presidents give higher lexical prominence to specific place names (Baltic, Vilnius, Aglona, Latgale), the name of the country, international organisations (EU, NATO, UN), values such as democracy and independence, as well as such words as centenary, millennium, transatlantic, demography and transformation referring to specific issues and topics in the current and future political environment in the countries.

\section{CONCLUSIONS}

The results of the keyword and KWIC analysis in the corpora of the speeches of the presidents of Estonia, Latvia and Lithuania show that all the presidents tend to use the name of the state as well as personal pronouns referring to ingroups (we, us, ours) denoting the unity of people repeatedly throughout the speeches. The keyword use seems to be more frequent during the period from 1991 to 2015 (Latvia and Estonia) and subjected to gradual increase in the case of Lithuania. The presidents of Estonia focus more on the statehood and singularity of Estonia, while the presidents of Latvia and Lithuania emphasize the relationship of the states with other countries and international organisations in terms of security and development (more emphasized by male presidents).

Independence Day speeches focus on historical events in terms of freedom, security, independence (Latvia), cooperation with other countries (Lithuania and Latvia), work of the government (Estonia and Lithuania) and summarising the values and accomplishments that denote singularity and unity of people (Estonia). The speeches on the occasion of catholic celebrations seem to emphasize national values (in the case of Latvia) such as family, belief, love and hope more than other types of speeches, while the New Year and Christmas 
greeting speeches tend to be shorter than other speeches and mostly focus on congratulations and future goals (in the case of Estonia and Lithuania) and the feeling of unity (in the case of Latvia).

Furthermore, the speeches by the female presidents seem to focus more on the construction of the national spirit (homo) and the feeling of unity, while the male presidents seem to emphasize the common political past and its impact on the present situation as well as the importance of international cooperation for the better future. Likewise, the results indicate that there is a slight influence of political affiliation or ideology on the lexical choices of the presidents those representing socialist and liberal/conservative parties tend to emphasize international relations, while the nationalist presidents and the party independent presidents emphasize ideas of democracy, independence, freedom and the state as national body at present and in the future.

Consequently, it is concluded that corpus tools can assist CDA in various ways - the issues of representability and credibility, identifying thematic areas with keywords, identifying the use of linguistic means such as rhetorical questions or specific pronouns, and principled incorporation of corpus-driven and corpus-based approaches into CDA can help support analysts' arguments about texts and discourses; nevertheless, a detailed qualitative and critical analysis of the whole texts and the linguistic means applied therein is mandatory to draw definite conclusions.

\section{REFERENCES}

Allan, R. (2018). Recycling the data: building and using a learner Business English writing corpus. I Call Your Data: Proceedings of the XIXth CALL Conference. Antwerp. Available from http://miun.diva-portal.org/smash/get/diva2:1250868/FULLTEXT01.pdf [Accessed on 29 September 2019].

Baker, P. (2006) Using Corpora in Discourse Analysis. New York and London: Continuum Publishing.

Baker, P. (2012) Contemporary Corpus Linguistics. New York: Continuum International Publishing.

Flowerdew, J. and Richardson, J. E. (2017) The Routledge Handbook of Critical Discourse Studies. New York: Routledge.

Haider, A. S. (2017) Using Corpus Linguistic Techniques in Critical Discourse Studies: Some Comments on the Combination. Department of Linguistics. The University of Canterbury. Available from https://www.researchgate.net/publication/317045137_Using_Corpus_ Linguistic_Techniques_in_Critical_Discourse_Studies_Some_Comments_on_the _ Combination [Accessed on $\overline{15}$ October 2019].

Joseph, J. E. (2006) Language and Politics. Edinburgh: Edinburgh University Press.

Lane, T. (2008) Nationalism and national identity in the Baltic States. Journal of Area Studies, 2 (4): 56-70. Available from 10.1080/02613539408455706 [Accessed on 15 September 2018].

Levits, E. (2013) Preamble of the Constitution of Latvia. Available from http://saeima.lv/en/ news/saeima-news/22361-saeima-expands-the-constitution-with-a-preamble [Accessed on 17 September 2018]. 
McEnery, T. and Hardie, A. (2012) Corpus Linguistics: Method, Theory and Practice. New York: Cambridge University Press.

Mulderrig, J. (2008) Using keywords analysis in CDA: discourses in the knowledge economy in education. In B. Jessop, N. Fairclough and R. Wodak (eds.) Education and the Knowledgebased Economy in Europe. Educational Futures: Rethinking Theory and Practice, Sense (pp. 149-169). Rotterdam: Sense Publishers.

O’Keeffe, A. (2006) Chapter 6 Creating identities. Investigating Media Discourse (pp. 127-156). London and New York: Routledge.

O'Keeffe, A. and McCarthy, M. (2014) The Routledge Handbook of Corpus Linguistics. London and New York: Routledge.

Taagepera, R. (2018) Estonia: Return to Independence. Routledge: London and New York. Available from https://doi.org/10.4324/9780429500725 [Accessed on 20 October 2019].

The Supreme Council of Estonia (1992) Preamble of the Constitution of Estonia. Available from: http://www.concourt.am/armenian/legal_resources/world_constitutions/constit/ estonia/estoni-e.htm [Accessed on 17 September 2018].

The Supreme Council of Lithuania (1992) Preamble of the Constitution of Lithuania. Available from: http://saeima.lv/en/news/saeima-news/22361-saeima-expands-the-constitutionwith-a-preamble [Accessed on 17 September 2018].

Thomas, J. (2017) Discovering English with Sketch Engine. Brno: Versastile.

Wodak, R. and Meyer, M. (2016) Methods of Critical Discourse Analysis. London: Sage Publications Ltd.

Wodak, R., de Cillia, R., Reisigl, M. and Liebhart, K. (2009) Discursive Construction of National Identity. London and New York: Routledge.

Žagar, I. Ž. (2011) The use and misuse of topoi: Critical Discourse Analysis and Discourse Historical Approach. Proceedings of the 7th Conference of the International Society for the Study of Argumentation. Amsterdam: SicSat.

\section{CORPUS TOOLS}

Anthony, L. (2012) AntConc (Version 3.3.2) [Windows 3.5.7.]. Tokyo, Japan: Waseda University. Available from http://www.antlab.sci.waseda.ac.jp/ [Accessed on 30 September 2018].

Sketch Engine Tool Online. Available from https://app.sketchengine.eu [Accessed on 30 September 2018].

\section{SOURCES ANALYSED}

[Online 1] Speeches by the President of Estonia retrieved from the Homepage of the President of Estonia. Available from https://president.ee/et/ [Accessed on 12 September 2018].

[Online 2] Speeches by the President of Latvia retrieved from the Homepage of the President of Latvia. Available from https://www.president.lv/lv [Accessed on 12 September 2018].

[Online 3] Speeches by the President of Lithuania retrieved from the Homepage of the President of Lithuania. Available from https://www.lrp.lt/lt [Accessed on 12 September 2018]. 


\section{APPENDIX 1}

\section{Table 1 Preambles of Estonia, Latvia and Lithuania}

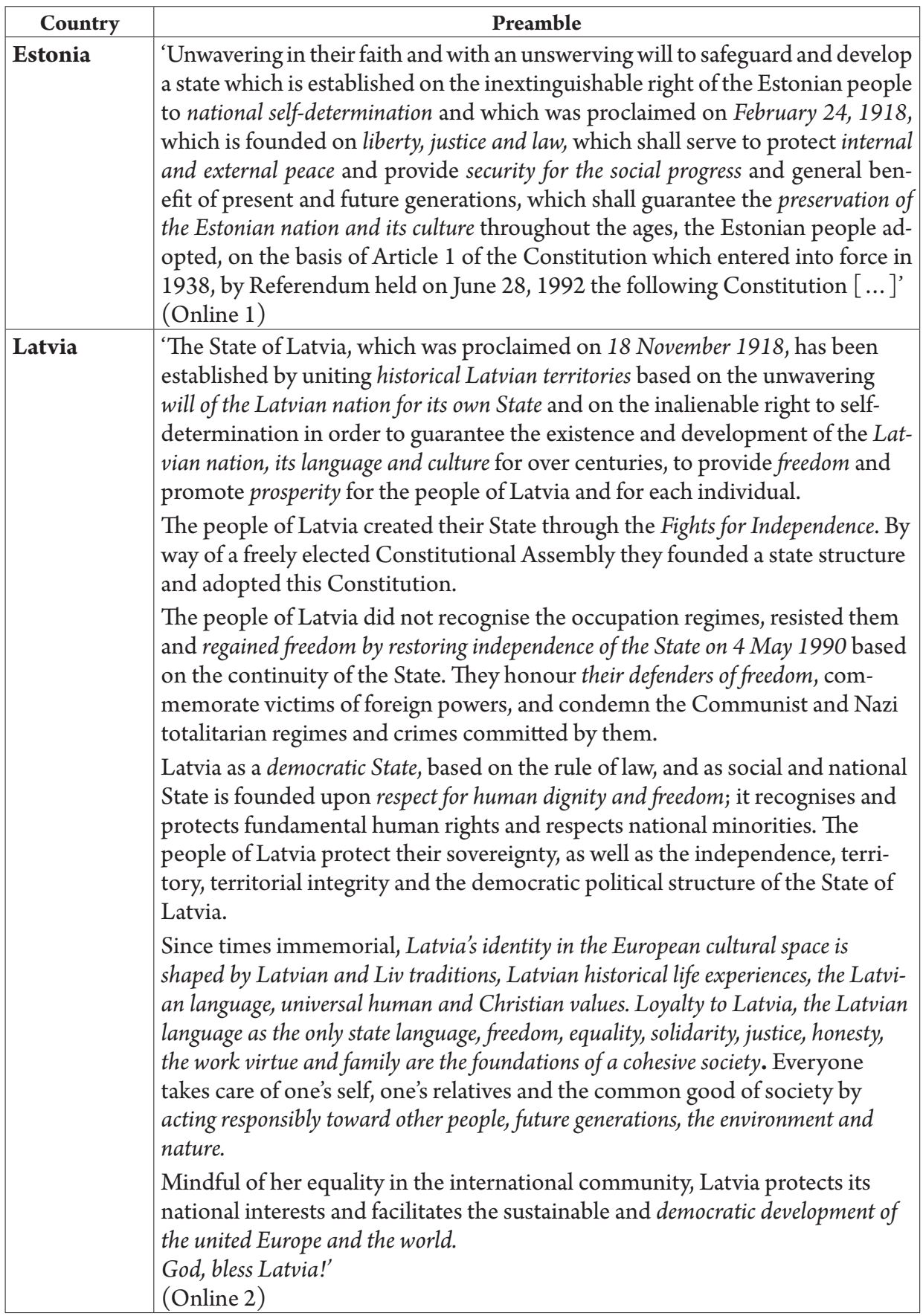




\begin{tabular}{|l|l|}
\hline Lithuania & 'The Lithuanian Nation \\
- having established the State of Lithuania many centuries ago, \\
- having based its legal foundations on the Lithuanian Statutes and the Con- \\
- having for centuries defended its freedom and independence, \\
- having preserved its spirit, native language, writing, and customs, \\
- embodying the inborn right of each person and the People to live and create \\
freely in the land of their fathers and forefathers, the independent State of Lithu- \\
ania, \\
- fostering national concord in the land of Lithuania, \\
- striving for an open, just, and harmonious civil society and law-governed State, \\
by the will of the citizens of the reborn State of Lithuania, approves and de- \\
clares this Constitution.' \\
(Online 3)
\end{tabular}

\section{APPENDIX 2}

\section{The List of Presidents}

\section{Estonia}

Lennart Meri (National Coalition)

$1992-2001$

Arnold Ruutel (People's Union, conservative)

2001-2006

Toomas Hendrik Ilves (Social Democrats)

2006-2016

Kersti Keljuhaid (party independent)

2016-present

\section{Latvia}

Jānis Čakste (Democratic Centre, agrarianism)

$1922(1918)-1927$

Gustavs Zemgals (Democratic Centre)

$1927-1930$

Alberts Kviesis (Farmer's Union - Euroscepticism)

$1930-1936$

Kārlis Ulmanis (independent)

$1936-1940$

Guntis Ulmanis (Farmer's Union)

1993-1999

Vaira Vỉke-Freiberga (independent)

1999-2007

Valdis Zatlers (independent)

2007-2011

Andris Bērziňš (Union of Greens and Farmers)

2011-2015

Raimonds Vējonis (Union of Greens and Farmers)

2015-2019

\section{Lithuania}

Algirdas Brazauskas (Social Democrats)

1993-1998

Valdas Adamkus (independent)

1998-2001 and 2004-2009

Rolandas Paksas (Order and Justice National party)

2003-2004

Arturas Paulauskas (Labour Party)

Dalia Grybauskaite (independent) 


\section{APPENDIX 3}

Table 2 Keywords and collocations in the speeches

\begin{tabular}{|c|c|c|c|}
\hline Word & $\begin{array}{c}\text { Raw } \\
\text { frequency }\end{array}$ & $\begin{array}{l}\text { Keyness in } \\
\text { comparison } \\
\text { to reference } \\
\text { corpus }\end{array}$ & $\begin{array}{c}\text { Collocates } \\
\text { (criteria for selection - minimum frequency } 5 \text {, } \\
\text { range } 3 \text { ) }\end{array}$ \\
\hline Estonia & 800 & 3850.59 & $\begin{array}{l}\text { Republic of, in, the, has, is, that, people, } \\
\text { independence }\end{array}$ \\
\hline Estonian & 362 & 2440.57 & $\begin{array}{l}\text { People, language, culture, independence, of, state, } \\
\text { nation }\end{array}$ \\
\hline Estonians & 61 & 633.58 & Fellow, dear, were, well, who, if, their, do, will, are \\
\hline Independence & 132 & 86.28 & $\begin{array}{l}\text { Restoration, day, war, happy, party, august, } \\
\text { national }\end{array}$ \\
\hline Republic & 110 & 62.99 & $\begin{array}{l}\text { President, Estonia, anniversary, of, at, on, } \\
\text { continuity, day }\end{array}$ \\
\hline Democratic & 75 & 59.01 & $\begin{array}{l}\text { Institutions, world, in, values, states, where, } \\
\text { country }\end{array}$ \\
\hline Democracy & 75 & 39.51 & $\begin{array}{l}\text { Participatory, liberal, representative, successful, } \\
\text { Russian, in, young, values, power }\end{array}$ \\
\hline Dear & 81 & 38.54 & $\begin{array}{l}\text { Friends, countrymen, theatre, compatriots, } \\
\text { fellow, hall }\end{array}$ \\
\hline politician & 65 & 26.82 & $\begin{array}{l}\text { Officials, who, by, has, all, from, have, are, or, } \\
\text { Estonian }\end{array}$ \\
\hline freedom & 107 & 21.56 & $\begin{array}{l}\text { Speech, press, chose, choice, everything, use, } \\
\text { sense, our, their }\end{array}$ \\
\hline $\begin{array}{l}\text { Latvia Godāt* } \\
\text { (Honour*) }\end{array}$ & 65 & 26.48 & $\begin{array}{l}\text { Augsti (highly), kungi (gentlemen), deputāti } \\
\text { (MPs), kundze (ladies) }\end{array}$ \\
\hline NATO & 65 & 17.62 & $\begin{array}{l}\text { Paplašināšanās (expansion), ES (EU), Savienības } \\
\text { (union), valstu (states), Eiropas, dalībvalsti } \\
\text { (member), Krievijas (Russia) }\end{array}$ \\
\hline $\begin{array}{l}\text { Neatkariba } \\
\text { (independence) }\end{array}$ & 63 & 14.08 & $\begin{array}{l}\text { Atjaunošanas (restoration), atgūšanas } \\
\text { (regaining), pēc (after), kopš (since), } \\
\text { proklamēšanas (proclamation), šì (this), savas } \\
\text { (our), Latvijas }\end{array}$ \\
\hline Latgale & 61 & 11.2 & $\begin{array}{l}\text { nav iedomājama (not imaginable), vārdi (words), } \\
\text { bez (without), es (I), Latviju, ar (with), ir (is) }\end{array}$ \\
\hline $\begin{array}{l}\text { Tauta (people/ } \\
\text { folk) }\end{array}$ & 321 & 10.43 & $\begin{array}{l}\text { Latvijas, mūsu (our), latviešu (Latvian), zeme } \\
\text { (land), padome (council), brīvība Freedom), } \\
\text { savu (your-our), spēku (strength) }\end{array}$ \\
\hline $\begin{array}{l}\text { Savieniba } \\
\text { (union) }\end{array}$ & 188 & 10.27 & $\begin{array}{l}\text { Eiropas, NATO, Rietumeiropas, Zemnieku } \\
\text { (farmers), kontekstā (context), Padomju } \\
\text { (soviet), Krieviju (Russia) }\end{array}$ \\
\hline
\end{tabular}




\begin{tabular}{|c|c|c|c|}
\hline Word & $\begin{array}{c}\text { Raw } \\
\text { frequency }\end{array}$ & $\begin{array}{l}\text { Keyness in } \\
\text { comparison } \\
\text { to reference } \\
\text { corpus }\end{array}$ & $\begin{array}{c}\text { Collocates } \\
(\text { criteria for selection - minimum frequency } 5 \text {, } \\
\text { range } 3)\end{array}$ \\
\hline $\begin{array}{l}\text { Drošiba } \\
\text { (security) }\end{array}$ & 166 & 9.52 & $\begin{array}{l}\text { Pieminekḷa (monument), tauta (people), Dievs } \\
\text { (God), Latvijas, vērtības (values), svētkos } \\
\text { (celebration) }\end{array}$ \\
\hline Mūsu (our) & 590 & 9.1 & $\begin{array}{l}\text { Politikas (politics), Eiropas, telpu (space), jomā } \\
\text { (sphere), aizsardzības (protection), aspektā, } \\
\text { Latvija, ANO }\end{array}$ \\
\hline $\begin{array}{l}\text { Briviba } \\
\text { (freedom) }\end{array}$ & 80 & 8.04 & $\begin{array}{l}\text { Valsts (country), ir (is), tautas (people), dzīves } \\
\text { (life), rokās (in hands) }\end{array}$ \\
\hline $\begin{array}{l}\text { Nākotne } \\
\text { (future) }\end{array}$ & 113 & 7.87 & $\begin{array}{l}\text { Pārskatāmā (nearest), Latvijas, veidot (create), } \\
\text { es (I), redzējums (view), mūsu (our), pieder } \\
\text { (belongs), ticu (believe) }\end{array}$ \\
\hline Lithuania & 679 & 5140.06 & $\begin{array}{l}\text { Republic of, in, is, state, that, will, people, was, } \\
\text { has }\end{array}$ \\
\hline Lithuanian & 132 & 1467.57 & $\begin{array}{l}\text { Council, people, language, members, conference, } \\
\text { therefore }\end{array}$ \\
\hline NATO & 53 & 132.51 & $\begin{array}{l}\text { Union, membership, European, expansion, good, } \\
\text { EU, member, today }\end{array}$ \\
\hline independence & 81 & 85.99 & $\begin{array}{l}\text { Freedom, years, regained, restoration, restored, } \\
\text { anniversary, for, was, Lithuania's, state }\end{array}$ \\
\hline Union & 125 & 57.15 & $\begin{array}{l}\text { European, NATO, Western, Soviet, member, into, } \\
\text { will, we, should }\end{array}$ \\
\hline nations & 50 & 52.58 & United, organisation, other, has, the, by, in, is, of \\
\hline European & 206 & 47.99 & $\begin{array}{l}\text { Union, NATO, membership, integration, central, } \\
\text { nations, member, the, into, other, countries }\end{array}$ \\
\hline freedom & 127 & 41.55 & $\begin{array}{l}\text { Rights, independence, democracy, spirit, live, for, } \\
\text { and, our, human, their, regained, who, fighters, } \\
\text { also, ideals }\end{array}$ \\
\hline $\mathbf{E U}$ & 54 & 38.45 & $\begin{array}{l}\text { Membership, member, NATO, members, states, } \\
\text { relations, with, will, on, the, by, and, Lithuania }\end{array}$ \\
\hline nation & 201 & 36.09 & $\begin{array}{l}\text { Our, of, the, European, other, and, state, states, a, } \\
\text { by, will, Lithuanian, are, free }\end{array}$ \\
\hline
\end{tabular}

Lìga Romāne-Kalniņa (Mg. Philol.) is a doctoral student of linguistics at the University of Latvia. Her research interests include political discourse, critical discourse analysis and corpus linguistics. Email: ligaromane@inbox.lv 